\title{
Knowledge Integration and Good Marine Governance: A Multidisciplinary Analysis and Critical Synopsis
}

\author{
Margherita Paola Poto ${ }^{1,2}$ (]) Annegret Kuhn ${ }^{3} \cdot$ Apostolos Tsiouvalas $^{4} \cdot$ Kara K. Hodgson $^{4} \cdot$ \\ Montoya Valentina Treffenfeldt ${ }^{3} \cdot$ Christine M.Beitl $^{5}$
}

Accepted: 14 October 2021 / Published online: 25 October 2021

(C) The Author(s) 2021

\begin{abstract}
Our research addresses knowledge integration for the good governance of the environment and the oceans: (a) through a comprehensive legal, political science, and anthropological analysis; and (b) by providing an examination of crucial research foci and research gaps in the fields of environmental and marine governance, along the North-South divide. Our subsequent critical synopsis reveals how existing research within each discipline offers complementary insights for future research. We concludes with a call for further testing of tools, approaches, and methods to enable comprehensive research on the conceptualization of knowledge integration.
\end{abstract}

Keywords Environmental and marine (ocean) governance $\cdot$ Multidisciplinary analysis $\cdot$ Research-synopsis $\cdot$ Indigenous knowledge

\section{Introduction}

Knowledge integration and participatory governance that engage stakeholders in integrated decision-making are of paramount importance for the protection of the oceans. In the last 50 years, states have adopted many international environmental treaties in response to environmental threats (Birnie et al., 2009; Brown Weiss, 2011). One of the major

Margherita Paola Poto

margherita.p.poto@uit.no

Annegret Kuhn

akuhn@politik.uni-kiel.de

Apostolos Tsiouvalas

apostolos.tsiouvalas@uit.no

Montoya Valentina Treffenfeldt

v.treff.mon@gmail.com

Christine M.Beitl

christine.beitl@maine.edu

Uit The Actic University of Norway, Troms $\varnothing$, Norway

2 Department of Management, University of Turin, Turin, Italy

3 CAU Kiel University, Kiel, Germany

4 NCLOS, Uit The Arctic University of Norway, Troms $\varnothing$, Norway

5 University of Maine, Orono, ME, USA problems in marine governance is fragmentation and lack of coordination across issues, not least due to sectoral regulation and inadequate knowledge integration (Boyes \& Elliott, 2014; van Tatenhove, 2011). A lack of coordination among different sectors has produced inadequate responses to both threats to the marine environment and the need for climate change mitigation. As a response to environmental degradation, an emerging paradigm in marine governance encourages adoption of a holistic, cross-disciplinary, and transboundaryintegrated approach (Grip, 2017). This paradigm underlines the need to adopt a multi-actor perspective to promote crosssectoral cooperation, coordination, and knowledge-sharing in ocean governance (Cicin-Sain, 1993; Grip, 2017; Harrison, 2015; Koskenniemi, 2006; Olsen et al., 1998). To achieve this requires further interdisciplinary marine research to develop a new knowledge culture (Christie, 2011; Hind, 2014; Turner et al., 2017) to be translated into politics through epistemic communities (groups of experts with a common policy goal to protect and conserve the oceans) (Haas, 1992). In particular, there is increasing attention in research on ocean governance to the importance of indigenous knowledge (IK), indigenous and traditional knowledge (ITK), traditional knowledge (TK), traditional local knowledge (TLK), as well as local ecological knowledge (LEK). Epistemic communities on ocean governance rely on shared knowledge to develop a common base to respond to the need to provide good governance of the oceans. 
This article stems from an interdisciplinary expert workshop on indigenous and traditional knowledge integration organized by Kuhn and Poto in November 2019 and provides an overview of current of research and knowledge advancement through a multi-disciplinary analysis of the concept of knowledge integration in law, political sciences, and anthropology. During the workshop, a broad range of best practices, challenges, and research gaps in the context of knowledge systems integration were discussed using exploratory research (Reiter, 2017) that are further condensed and systematized. We also provide a critical examination of crucial research foci and research gaps on sustainable marine governance and knowledge integration in the three selected disciplines, which have increasingly focused their attention on the matter.

We chose the broad categories of indigenous knowledge (IK), indigenous and traditional knowledge (ITK), traditional knowledge (TK), traditional local knowledge (TLK), as well as the more specific term of local ecological knowledge (LEK) based on the dominant terms used in literature within social sciences (Nelson \& Shillings, 2018). Moreover, the need to give voice to the unheard and the vulnerable (UNDP, 2018) justifies the choice of focus on indigenous and local knowledge.

We investigate the application of such categories within the context of marine and ocean governance (we use the terms interchangeably) as "the sharing of policy-making competencies in a system of negotiation between nested governmental institutions at several levels $[\ldots]$ on the one hand and state actors, market parties and civil society organizations of different maritime activities on the other hand, in order to govern activities at sea and their consequences" (van Tatenhove, 2011).

Our objectives include: 1) identification of specific research foci and insights, including major research gaps within existing research; 2) overview of methods used across the literature; 3 ) a focus on best practice approaches as highlighted by the three disciplines; and 4) development of a critical synopsis using a the results of our three-disciplinary analysis. We consider this approach and its potential for expansion to other scientific disciplines a necessary basis for developing overarching concepts and principles within ocean governance research. Our results contribute to building a common understanding for researchers across disciplines to address common challenges in the field of marine governance.

We present a systematic research overview of research on indigenous and traditional knowledge integration in the governance of natural resources - especially marine resources - in law, political science (particularly the subfield of international relations), and anthropology. We address three main aspects: 1) specific research foci and insights, including major research gaps within the exiting research field; 2) methods used in the different strands of literature; and 3) potential best practice approaches as highlighted by the three fields.

\section{Legal Studies}

Indigenous traditional knowledge (ITK) in legal research has developed through two main and sometimes intersecting lines of inquiry: nature's rights (increasingly recognized as also held by ITK keepers) and indigenous rights legal recognition (Nijar, 2013). Protecting and including ITK in environmental governance complement recognition of procedural environmental rights of Indigenous peoples, such as access to information, the right to participate in decisionmaking, the right to justice in environmental matters, and the right to free, prior, and informed consent (Poto, 2021).

Recognition of the role ITK was first associated with the protection of fundamental rights to life, health, and food and later extended to the protection of environmental rights related to biodiversity conservation and protection, and finally to the protection of Indigenous rights. For example, since its establishment in 1945 the United Nations Food and Agriculture Organization's (FAO) programs have incorporated ITK on a wide range of issues, including farmers' rights, poverty alleviation, nutrition and health, and gender equity. A first effort to protect ITK was a joint initiative by the World Intellectual Property Organization (WIPO) and the United Nations Educational, Scientific, and Cultural Organization (UNESCO) in 1978 that led to the WIPO Model Law on the Protection of Expressions of Folklore Against Illicit Exploitation and Other Prejudicial Actions in 1982 (Kutty, 2002). The protection of ITK in relation to genetic resources was introduced by FAO in 1996 (World Food Summit Plan of Action, 1996: source FAO, 2009), and similar initiatives continue (FAO, 2009). The United Nations Framework Convention on Climate Change (UNF$\mathrm{CCC}$ ) and the Intergovernmental Panel on Climate Change (IPCC) have also acknowledged the importance of ITK in addressing climate threats (UNFCCC, 1992).

The 1992 Convention on Biological Diversity (CBD, 1992) is unanimously recognized as the first international hard law instrument to enshrine the connection of Indigenous and local communities' traditional knowledge to the protection and conservation of biological diversity (Mauro \& Hardison, 2000; Nijar, 2013). Article 8(j) of the CBD acknowledges the central role of ITK in protecting and enhancing biodiversity, and consequently requires governments to implement measures that (1) respect, preserve, and maintain traditional knowledge, innovations, and practices, (2) promote and encourage the application and increased use of traditional knowledge, innovations, and practices with the approval and participation of Indigenous and local communities, and (3) 
ensure that the benefits derived from the use of traditional knowledge, innovations, and practices are fairly shared with the corresponding communities (Amiott, 2003). The introduction of the concept of sustainable development and its recognition in the 1992 Rio Declaration on Environment and Development endorsed this recognition. Principle 22 of the Rio Declaration in particular links environmental procedural rights (rights for nature) and indigenous rights. It states that Indigenous peoples and their communities play a key role in environmental management because of their knowledge, and consequently States have the obligation to enable their participation in environmental decision-making. Aiming to provide guidance, amongst others, on the enforcement of the CBD's Article 8(j) into national jurisdictions, The 2002 Bonn Guidelines on Access to Genetic Resources and Fair and Equitable Sharing of the Benefits Arising out of their Utilization providing guidance on Article 8(j) were adopted by the CBD, followed in 2004 by the Akwé: Kon Guidelines, which refer to a Mohawk term meaning "everything in creation," that provide a collaborative framework to ensure full involvement of Indigenous and local communities in impact assessment processes, emphasizing the holistic nature of indigenous knowledge (Markkula et al., 2019). In 2010, the Conference of the Parties to the CBD adopted the Nagoya Protocol on Access to Genetic Resources and the Fair and Equitable Sharing of Benefits Arising from their Utilization to the Convention on Biological Diversity. As of 2020, the Protocol has been ratified by 126 states and grants two sui generis rights to Indigenous peoples in respect of their traditional knowledge: the right to obtain free, prior, and informed consent (FPIC) for the use of traditional knowledge (Article 7), and the right to equitably share benefits arising from the use of traditional knowledge (Article 5(5)) (Buck \& Hamilton, 2011). The Mo'otz Kuxtal Voluntary Guidelines elaborate further on the concept of FPIC in relation to ITK and benefit-sharing, and protect it against unlawful appropriation, also drafted under the CBD's umbrella in 2016. Finally, in 2018 the CBD adopted the Rutzolijirisaxik Voluntary Guidelines for the Repatriation of Traditional Knowledge Relevant for the Conservation and Sustainable Use of Biological Diversity (AM, 2019).

As noted, the development of specific international instruments dealing with the rights of Indigenous peoples further fostered the protection of traditional knowledge. The International Labor Organization's Convention 169 of 1989, while not explicitly mentioning 'traditional knowledge,' ensures the protection of knowledge and ways of life of Indigenous peoples, listing amongst others, traditional preventive care and healing practices, as well as spiritual values, knowledge, and technologies. Of crucial importance to ensure the development of ITK was the adoption of the 2007 UN Declaration of the Rights of Indigenous Peoples (UNDRIP) which, even though non-binding, is considered a milestone in the development of indigenous rights. The preface of UNDRIP reaffirms the importance of ITK towards achieving sustainable development and protection of the natural environment. Article 31 recognizes the right to maintain, control, and protect traditional knowledge systems in all manifestations. To implement international law, States have enforced national laws that reaffirm the protection of traditional knowledge and its incorporation in resource management policies (for Norway, see Jakobsen \& Poto, 2016).

The recognition of ITK fits into the fabric of the environmental rights' protection and indigenous rights recognition also in the context of the law of the sea and ocean governance. This link is particularly evident in ongoing debates regarding legislative protection in Areas Beyond National Jurisdiction (ABNJ). Even though the UN Convention of the Law of the Sea (UNCLOS, 1982) is silent on the role of ITK for the protection of the marine environment, ABNJ legal experts are increasingly realizing the relevance of traditional knowledge in informing the application of ecologically oriented principles, such as ocean connectivity and adjacency. In this context, ITK is believed to play a central role in enriching the knowledge of biological and ecological information on species distribution, as well as on climate change impacts on the oceans, and mitigation and adaptation strategies. In other words, many legal scholars and policymakers share the opinion that "the knowledge, innovations, and practices of Indigenous peoples and local coastal communities can enrich the diversity of available approaches and solutions and elaborate on principles that are of direct relevance for the governance of marine areas beyond national jurisdiction" (Dunn et al., 2017). Nevertheless, the doctrine seems to be vague on effective ways to include ITK in the ocean governance regulatory framework, merely stating that there is a need for 'strengthening' the use of traditional knowledge and 'incorporating' traditional knowledge in the implementation of CBD measures at sea.

Specific recognition of ITK in the context of environmental procedural rights and indigenous rights at the regional level is found in the Agreement to Prevent Unregulated High Seas Fisheries in the Central Arctic Ocean, which emphasizes how such recognition of indigenous knowledge, albeit specifically limited to the Arctic region, is a result of a participatory effort of Indigenous representatives in environmental decision-making and explicitly recalls UNDRIP (Schatz, 2019), although the dilemma of how to effectively implement such recognition remains outstanding.

\section{Research Gaps}

Although there has been incremental progress regarding the recognition and legitimization of ITK through the above-mentioned instruments, legal scholars often problematize the way international law approaches and 
'governs' ITK (Fan, 2014), as well as the way ITK provisions are operationalized in domestic legislative or policy measures (Amiott, 2003; Nijar, 2013). It has been argued that Western intellectual property rights, and particularly the concept of benefits-sharing as stated in the CBD, are unsuitable for protecting traditional knowledge systems because of their focus on individual property, limitedness in time, and formal requirements, whereas ITK is often communally or collectively created, transmitted through intergenerational transfer, and is not always recorded in material form (Forsyth, 2013).

Furthermore, the adequacy of the existing international regime to acknowledge indigenous knowledge systems holistically and treat them appropriately, particularly regarding traditional knowledge vis-à-vis science, is also questioned (Casimirri, 2003; Mazzocchi, 2006; Nijar, 2013). If international law continues to prioritize knowledge produced by cognitive, rational processes and that use mainly present current scientific data, traditional knowledge will be treated merely as a subset of scientific knowledge, partially used, or even appropriated (Mazzocchi, 2006). For instance, Principle 15 of the Rio Declaration on sustainable development mentions states: 'Where there are threats of serious or irreversible damage, lack of full scientific certainty shall not be used as a reason for postponing cost-effective measures to prevent environmental degradation.' While the Declaration explicitly advocates the protection and acknowledgment of traditional knowledge systems, Trippett (2000) observed that this provision calls for policy-makers to apply a precautionary approach exclusively grounded on scientific evaluations, excluding those knowledge systems of societies observe how nature responds to human activities. By treating the use of traditional knowledge mainly as a human rights issue, there is a risk of marginalizing ITK from discussions within international environmental law fora where the meaning and operation of the precautionary principle are negotiated.

Legal scholarship has underlined a need for domestic legal frameworks that 'include' traditional knowledge systems as a whole rather than 'integrating' specific elements of this knowledge (Casimirri, 2003). This could help safeguard against misusing, appropriating, and decontextualizing ITK, in whole or in part. Forsyth (2013) suggests that an alternative approach, such as ITK, is imperative to escape the hegemonic Western perspective of knowledge and open up a new regulatory space wherein customary institutions of Indigenous communities shall be responsible for the utilization of ITK, coexisting with state legal instruments and not merely treated as diametrically opposite. In that respect, pluralism may serve as a fruitful avenue for interpreting and contributing to the shaping of contemporary legal frameworks where Western-based science and knowledge coexist and co-evolve with traditional knowledge systems (Forsyth, 2013; Tsiouvalas, 2020).

\section{Political Science IR Research}

\section{Complementary Contributions and Research Gaps}

There is very little systematic research within current international relations (IR) literature explicitly focusing on political inclusion of indigenous or traditional knowledge in marine resource governance - or governance of natural resources in general. Indigenous inclusion is mainly discussed within the more general topic of non-state actors' participation in global governance - especially environmental and natural resources governance, where a quite large and differentiated body of IR literature has emerged during the last 20 years (Betsill \& Correl, 2001; Gereke \& Brühl, 2019; Scholte, 2011; Tallberg et al., 2013).

Scientific discussions in IR have focused on the causes for, and particularly the impact of, different kinds of nonstate actors on the effectiveness, political authority, and legitimacy of international organizations and regimes. The category of non-state actors includes non-governmental organizations (NGOs), multinational corporations, social movements, and local communities. Where indigenous participation has been analyzed research focuses mostly on indigenous representation within the United Nations system (e.g., Hasenclever \& Narr, 2019). Empirically, this has mostly been within single case studies of international environmental institutions and especially climate change institutions, under the umbrella of the United Nations Framework Convention on Climate Change (UNFCCC). The most common methods for data collection and analysis are qualitative (predominantly analyses of organizational documents, supplemented by interviews with political actors). More recently there have been several broad comparative studies of a larger set of international organizations and regimes in different policy areas (Betsill \& Correl, 2001; Tallberg et al., 2013).

Political participation of Indigenous people within international institutions is especially pronounced within the regional forum of the Arctic Council (AC) ${ }^{1}$ and there are various studies with a distinct empirical focus on the Arctic region (Bennett, 2020; Coote, 2016; Shadian, 2017). While ultimate authority over Arctic governance remains securely

\footnotetext{
${ }^{1}$ The AC was established in 1996 as an intergovernmental forum for common Arctic issues, particularly environmental protection and sustainable development. Its founding document, the Declaration on the Establishment of the Arctic Council (commonly referred to as the Ottawa Declaration), categorized three layers of participants: Member States, Observers, and Permanent Participants. Where this forum is unique is in its exclusive PP category for which only organizations representing Arctic Indigenous peoples are eligible. PPs occupy a liminal space; they are considered full members of the AC, which means they have more authority than Observers. However, they still lack the decision-making abilities of Member States.
} 
within the domain of states, the Permanent Participants (PP) category "has constituted a historic shift in IR" (Shadian, 2017) because this is the first and only instance of its kind. The studies of Coote (2016) and Bennett (2020) critically focus on the participation of Indigenous people's organizations in the AC and argue that, despite the formally institutionalized status of PPs with the rights of participation and consultation, the inclusion of Indigenous voices (much less their knowledge, specifically) in practice is still largely aspirational. The primary barrier is a lack of adequate funding, without which PPs might not be able to attend meetings where their voices would be heard. One solution the AC has offered has been to encourage PPs to form partnerships with businesses and the AC Observer States to facilitate their full participation. Bennett (2020) investigates specific partnerships between PPs and the AC Observer States of Singapore and South Korea. A secondary barrier is the reinforcement of hierarchy by States. As Coote (2016) notes, "If the PPs wish to engage in a discussion on fisheries, security, or rights-based discourses - which are not formally within the Council's competence and/or not acceptable to certain states - that point of order is not likely to be taken up for serious discussion at the meeting."

Traditionally the subject of non-state actor participation in marine resource governance has not received very much attention from IR scholars (with a few exceptions concerning the International Whaling Commission, see Andersen \& Gulbrandsen, 2003; Skodvin \& Andresen, 2003). However, in the course of (a) generally increasing political as well as scientific interest in ocean governance, and (b) growing analyses of marine spatial planning policies during the last ten years, non-state actors in multi-level marine governance (although not specifically Indigenous actors) have begun to receive some more attention (e.g., Petersson et al., 2019).

Non-state actor participation has commonly been subdivided into formal and informal participation (for the reciprocal influence of both dimensions, see Schroeder \& Lovell, 2011). In practice, formal participation is often guaranteed to non-state actors as "observers" in international organizations or at inter-governmental conferences and other organizational meetings. Empirical findings show a strong increase in this kind participation since the 1990s (Nasiritousi, 2019). But research also indicates that Indigenous peoples' political participation or representation at the international level is still relatively small when compared to other groups of nonstate actors (Nasiritousi, 2019). Informal participation activities of non-state actors vary. They can range from lobbying and advocacy - mostly agenda-setting, agenda-shaping of policy-making processes, and shaping existing norms more broadly - to public protest and mobilizations.

Some authors have studied the factors conditioning effective (mostly formal) participation of non-state actors, including Indigenous representatives (for more detailed findings regarding the Arctic region see Coote, 2016). Most authors argue that increasing non-state actor participation enhances the legitimacy of international institutions by increasing transparency in political decision-making processes, by fostering democratic representation, and by providing specialized expertise (Albin, 1999; Bernauer \& Gampfer, 2013; Biermann \& Gupta, 2011; Green, 2013). Some more critical authors stress that non-state actors should also be considered as advocates of specific group interests (Prakash $\&$ Gugerty, 2010). Moreover, some more recent empirical studies show a marked imbalance between non-state actors from the global South and the global North in accreditation in the UNFCCC Conference of Parties (COPS) (Gereke \& Brühl, 2019) and concerning formal participation in different regional fisheries management organizations (Peterrson et al., 2019).

Thus far, in the context of marine governance, or even in global environmental governance more generally, Indigenous actors have been mentioned most often as one example of non-state actor groups or subsumed under the category of NGOs - or more recently NGOs from the Global South. Despite the lack of more general research focusing on the participation of Indigenous actors in international environmental and ocean governance, there are some valuable exceptions. Once again research has a pronounced focus on the Arctic region -in particular, the Inuit Circumpolar Council (ICC), which represents the Indigenous communities of the Inuit as a transnational people and is an active and powerful organization in Arctic regional politics. Since its founding, the ICC has been a tireless advocate of Inuit interests, including their ITK, on the international stage. Fabbi (2015) contends that two declarations constitute an Inuit foreign policy: the Circumpolar Inuit Declaration on Sovereignty in the Arctic (2009), which recognizes the status of the Inuit as rights-holders, and the Circumpolar Inuit Declaration on Resource Development Principles in Inuit Nunaat (2011), which asserts the need to utilize Inuit knowledge side-by-side with scientific knowledge.

Focusing on the other dimension of interest, knowledge in global resource governance, IR scholarship mainly revolves around the role of so-called "expert knowledge" by nonstate actors in international institutions (Bäckstrand, 2003; Haas, 1992; Young, 1999). Liberal-institutionalist scholars have studied the conditions for scientific experts to effectively influence (environmental) global governance, mostly focusing on different factors of the institutional design of international organizations and regimes (Andresen et al., 2000; Young, 2004). Constructivist IR scholars have studied epistemic authority and knowledge in global governance and analyzed the embeddedness of knowledge in belief systems and norms, as well as the distribution of political power. Thus, the widely used concept of "epistemic communities," first introduced by John Ruggie (1975) and further 
developed by Peter Haas (1992), analyses how the knowledge of scientific communities translates into political power and influence. While these scholars have made a significant contribution for systematically studying the ways and extent to which non-state knowledge holders gather influence on international policies, empirical analyses have employed a quite narrow conceptualization of "expert" that rarely includes indigenous knowledge and knowledge holders. Only more recently have a few voices critically examined "expert knowledge" in global resource and climate change governance. Foyer and Kervran (2017) and Esguerra and Hell (2021) have begun to further differentiate the concept of epistemic communities and their political impact. Foyer and Kervran (2017) detected a process of increasing "scientisation of traditional knowledge" through the trend of close advocacy between scientific epistemic communities and indigenous organizations within global climate governance. By combining IR approaches with science and technology studies approaches, Esguerra and Hell (2021) analyzed the so-called participatory turn (Bäckstrand, 2003) in experts' organizations and find that global knowledge platforms seek epistemic authority by institutionalizing participation (inter alia through indigenous knowledge inclusion). This institutionalized participation in turn shapes knowledge production within these platforms in the sense of which knowledge is presented as legitimate, for example, traditional and local knowledge (TLK) inclusion within the AC. Brhlíková (2017) investigated the degree of importance with which TLK has been treated in the $\mathrm{AC}$ and notes that TK has been formally included as an area of importance since the AC's founding. The Ottawa Declaration officially recognizes "the traditional knowledge of the indigenous [sic] people of the Arctic and their communities and tak[es] note of its importance and that of Arctic science and research to the collective understanding of the circumpolar Arctic" (Arctic Council, 1996). In 2000, TLK was included on the agenda of two of the six WGs. Since 2015, it "has been partially included on the agenda of other working groups...However, its usability has been inconsistent and not developed to the same extent as on [the original two WGs]" (CAFF, 2017-2019). As one WG assessment exemplifies, the actual inclusion of TLK has lagged behind declarations of its importance: "[Despite efforts to include TK and TK holders] within its design and implementation, a lack of funding, support, and capacity hindered its effect within the Marine Expert Networks and this report" (CAFF, 2017-2019).

On a more general level, some of these reflections on knowledge and different knowledge systems in global resource and climate governance have been taken up by scholars of decolonial IR theories. Even though there has been no research in IR that focuses on marine resource governance from this perspective, the studies promote a critical rethinking of the status of Western scientific knowledge and the role and structure of international and national institutions (Agrawal, 1995; Diver, 2017). ${ }^{2}$ Linda Tuhiwai Smith (2012) critiqued the imperial status of Euro-centric methodologies and knowledge, which has marginalized indigenous ones, using the example of global and New Zealand's academic structures. Simpson (2004), in contrast, argues there is a growing interest in ITK, though, it has been used only to complement Western research in the realm of biodiversity. This is also seen in the few numbers of cited Indigenous scholars in the realm of ITK and within social science (Todd, 2016). Additionally, Flores (2008) states that in national and international legal norms ITK regarding biological diversity and intellectual property rights is protected in favor of the economic interest of Western states, rather than the full protection and recognition of ITK. In sum, the studies highlight that the unequal power relations between the West and the Other (Blaney \& Tickner, 2017) served to oppress and marginalize ITK in global (resource) governance (Lightfoot, 2016; Santos, 2016; Smith, 2012; Whitt, 2009).

Decolonial IR and political science have argued that (a) ITK needs to be performed and accepted in global (resource) governance, particularly concerning territorial and cultural rights, and self-determination (Lightfoot, 2016; Simpson, 2004); and (b) state and global political institutions must grant a high level of participatory rights to Indigenous actors to achieve a deeper bridging or mingling of the different knowledges (Latulippe \& Klenk, 2020; Lightfoot \& MacDonald, 2017; Santos, 2016). The authors used qualitative comparative and discursive analytical methods, in some cases grounded in indigenous methodologies (Lightfoot, 2016; Smith, 2012). Although decolonization is best based on local movements, the case studies have been applied mainly at the national level. At the same time, local counterhegemonic movements have often confronted norms established on the international level and vice versa. Empirical analyses have focused on (a) decision-making process(es) and resulting treaties, concentrating mainly on national rather than on international documents and treaties (Gissi et al., 2017; Lightfoot \& MacDonald, 2017; Maaka \& Fleras, 2009; Marimán \& Aylwin, 2008; Turner, 2006; Viaña Uzieda, 2009); (b) narratives of popular opinions about the relation between the modern nation-state and indigenous nations (MacDonald, 2013); and (c) interviews with Indigenous peoples (García \& Gualda, 2016; Lightfoot, 2016). Although, there is a difference concerning the ideas and concepts for governance approaches developed out of the empirical research to overcome unequal power relations in different nations with differing colonial past. Scholars studying the

\footnotetext{
${ }^{2}$ For this paper, Western scientific knowledge can be conceptualized as being "guided by empirical measurements and abstract principles that help order the measured observations to facilitate the testing of hypotheses" (Diver, 2017: 2).
} 
cases of Canada and New Zealand such as Lightfoot (2016), MacDonald (2013), and Maaka and Fleras (2009) developed theoretical governance concepts called bi-nationalism or syncretic democracy grounded on strong bottom-up approaches and a clearer difference between the settler state and Indigenous peoples, partly drawing on political constituents, which can be found in the governmental system in New Zealand. On the other hand, several case studies conducted in Latin America, for example Viaña-Uzieda (2009), and Santos (2016), have built on more inter-relational governmental concepts such as plurinationalism and interculturalism. However, there is still a research gap on comparing theoretical as well as existing national and regional marine governance concepts to integrate ITK in decision making, especially in states characterized by legal pluralism and interculturalism.

\section{Anthropological and Social-Ecological Systems (SES) Research}

The study of local knowledge systems or ethnoecology - a more encompassing term that may include local ecological knowledge (LEK), indigenous knowledge (IK), traditional ecological knowledge (TEK), folk knowledge, ancestral knowledge, traditional wisdom, traditional science, ethnobiology, and ethnomedicine -has foundations in ethnoscience. Since the mid-twentieth century, anthropologists have used qualitative, quantitative, and mixed-methods approaches to study folk knowledge. Indigenous knowledge is specifically understood as knowledge embedded in culture, passed down through generations, and structured around the integration of skills, institutions, customary practices, and values that have evolved over generations. With increasing concerns about the global loss of biodiversity and the erosion of cultural and linguistic diversity there has been a growing appreciation of how studies of indigenous and local knowledge systems can inform resource management and environmental governance.

Early research in ethnoscience focused on perceptions, beliefs, values, and skills about the environment (Atran, 1993; Fowler, 1977; Morrill, 1967; Sturtevant, 1964). The overall goal was to construct a theory about how members of a culture understand the natural world according to their cultural categories (Goodenough, 1957). The systematic study of folk taxonomies sought understanding of how cultural groups share and categorize information, and the degree to which folk knowledge corresponded with Western Scientific knowledge about the environment (Berlin et al., 1973; Bulmer, 1967). These early debates were driven by whether patterns of organizing information in the human mind are innate or influenced by culture. Since the 1980s, practical applications of ethnoecology in resource management, conservation, development, agriculture, and fisheries have been increasingly recognized (Johannes, 1981; Hunn, 1982; Rhoades \& Booth, 1982; Ruddle, 1994, 1995; Sillitoe, 1998). Notably, applications of TEK have informed critical issues in marine governance, including the design of marine protected areas (Aswani \& Hamilton, 2004; Aswani \& Lauer, 2006), fisheries management (García-Quijano, 2007; Garcia-Quijano \& Valdes-Pizzini, 2015), coral reef conservation (Levine $\&$ Feinholz, 2015), and a variety of other applications in artisanal aquaculture and community-based small-scale fisheries (Narchi et al., 2013). Many researchers have argued that societies have successfully managed their ecosystems based on LEK and customary marine tenure without "scientific data" (Johannes, 1978; Johannes et al., 2000; Ruddle, 1994; Ruddle \& Akimichi, 1984; Turner, 2020). This is especially important as pressure on marine environments continues to rise and with increasing concerns about the erosion of indigenous and ethnobotanical knowledge (Aswani et al., 2018) and the need to understand climate change impacts on subsistence hunting and life in northern communities Carothers et al., 2014).

Some studies aim to integrate LEK to understand patterns of change over time and space (De Freitas \& Tagliani, 2009; Lloret et al., 2015). Other researchers have employed ethnoecological methods to advance understanding of how different fish populations may be shifting in response to climate change (Lloret et al., 2015). In recognition of the ways ethnobiological work can contribute to studies of food security (), Beitl et al. (2020), reference work by Kuhnlein (2014), explore how changes in household consumption of mangrove resources respond to broader socio-environmental trends, such as a decline in available resources, population growth, and conflicts with industrial fleets. A growing body of SES research recognizes the critical value of LEK in historical ecology, particularly where data on historical trends are scarce or baselines non-existent (Bender et al., 2013; Early-Capistrán et al., 2020; Sáenz-Arroyo et al., 2005; Zapelini et al., 2019) and shed light on a number of conceptual, methodological, and ethical challenges concerning the representation of knowledge and the co-production of knowledge through collaborative, interdisciplinary methodologies (Belisle et al., 2018; Carothers et al., 2014).

Drawing on systematic data collection methods commonly employed in ethnoscience, many studies argue for the value of the cultural model approach and cultural consensus analysis that allow study of the complex interactions between knowledge systems and shared values underlying attitudes, decision-making, and actions within and across social groups (Feurt, 2006). Formal, structured data elicitation methods such as free lists, triads, similarity judgments, triad tests are often employed to define the boundaries of cultural domains (Garcia-Quijano \& Valdes-Pizzini, 2015). Once a cultural domain is defined, analysis and multi-dimensional 
scaling can generate knowledge scores of individual members of a group (Weller, 2007) and elicit information about cultural value orientation (Rickenbach et al., 2017), and conservation ethics (Atran et al., 1999; Casagrande, 2004; see also Paolisso, 2002, 2007; Paolisso \& Dery, 2010). Cultural models can also be constructed through open-ended interviews to elicit harvesters' relational understanding of marine species using the inductive logic of grounded theory (Farr et al., 2018). This approach can also be paired with rich, ethnographic data to document the extent to which perspectives are shared within and across communities while simultaneously considering the ways in which knowledge is embedded within larger worldviews and power relations (Carothers et al., 2014).

Applications in ethnoecology have also advanced several research methods that more directly engage local people through participatory and collaborative research approaches. De Freitas and Tagliani (2009) drew on LEK to construct a geodatabase in Southern Brazil as a tool for collaboration that encouraged stakeholders to think spatially about fishing effort and catch rates, prioritize survey efforts, identify zones of conflict. Participatory mapping is commonly used to better understand fine-scale patterns of marine resource use, local ecological knowledge, cultural values that may inform management practices, and conservation strategies (Aswani, 2011; Aswani \& Lauer, 2006;), and can also be used to elicit spatially explicit local ecological knowledge about habitat diversity, species distributions, and life cycle phases (Aswani, 2011; Aswani \& Hamilton, 2004; Aswani \& Lauer, 2006; Garcia-Quijano \& Valdes-Pizzini, 2015; Levine \& Feinholz, 2015; Zapelini et al., 2017). Mental maps are holistic and often contain additional information about social relations, histories, events, and patterns that may not be spatial (Levine \& Feinholz, 2015; McLain et al., 2013). Such approaches may ensure the participation of local populations in the production of scientific knowledge based on real-time, fine-scale observations.

Despite optimism about the potential value of LEK and IK in resource management applications, there this a fair amount of skepticism about the integration of knowledge systems. According to Garcia-Quijano (2015), local fishers "think ecologically" rather than categorically, quantitatively, or taxonomically, suggesting that fishers' understanding of the marine environment may focus on ecosystem processes such as habitat connectivity, temporal cycles, and patterns, and how target species respond to environmental change in trophic web dynamics, shifting populations, and habitat domains, and ecological indicators, which may lead to methodological challenges in integrating LEK with scientific knowledge. Similarly, Wohling (2009) notes that indigenous knowledge operates on a range of scales not easily adapted to the kinds of ecological disturbances caused by the contemporary society. Second, much of this research focuses on applications of ethnoecology with less attention to important cultural, ontological, and epistemological questions of how knowledge is produced, whom for, why, and how it may change in the process of ethnoecological research. Wohling (2009) argues that the extraction of Indigenous knowledge from its cultural context reduces the rich dynamic realities of the human experience to Western cultural categories that distort meaning and purpose. Nadasdy (2007) discusses ontological differences in non-Western societies that emphasize the importance of reciprocity and ethics in human interactions with non-humans, and the ways in which such perspectives are overlooked or dismissed by Western scientists and management institutions. In his discussion (1999) of how power relations determine which kinds of knowledge are privileged he cautioned that research in TEK and IK can have extractivist tendencies through its denial of existing power relations between aboriginal people and the state that contributes to their marginalization. These may not be meant to discourage TEK studies but highlight the importance of local engagement built on long-term trust, equity, and meaningful collaboration for all parties involved.

With increasing acknowledgement that Western Science is rooted in colonial histories, there are emerging calls for paradigm shifts toward decolonizing research, collaborative approaches, and the incorporation of Indigenous methodologies in the co-production of environmental knowledge (Atalay, 2019; Gordon, 2021; Smith, 2012; Todd, 2016; Turner, 2020; Velasquez Runk, 2014). In their discussion of best practices, Belisle et al. (2018) suggest that LEK "can reach its full potential" when integrated during the early stages of research design. Similarly, Velazquez Runk (2014) suggests that codesigning research, coanalyzing results, and coauthorship can enrich scientific understanding of ecology. Gordon (2021) describes a participatory method that provides a space for trust-building and story telling that allows participants to clarify their values and goals. On the other hand, McGreavy, state that the decolonization of academic institutions through a centering of indigenous research methods is still underdeveloped despite the potential of sustainability science to redress these inequities in their communities of practice.

\section{Discussion: Critical Synopsis of the Insights from the Three-Disciplinary Research}

\section{Lens, Results, and Gaps}

Insights from the three disciplines show complementary insights, diverging research gaps as well as some controversial aspects. We summarize the most important issues derived from the three-disciplinary research overview, 
which shall serve as the first basis for future multi, inter-, or transdisciplinary research on indigenous and traditional knowledge integration - including its potentials as well as challenges and pitfalls.

We refer to multidisciplinary research as the work of scholars from different disciplines conducted independently on a common problem or research question, while interdisciplinary research relies on shared knowledge. We conduct three-disciplinary (multi-) research, complemented with inter-disciplinary (conceptual synopsis) so that it is meaningful for any of these approaches individually or differently combined. $^{3}$

Knowledge integration is analyzed through the lenses of the rights-narrative in law, of the non-state actor participation narrative in political science IR, and of the ethnoculture and cultural model approaches in anthropology. As a result, the research in law and political science developed around the identification of subjects (rights-holders in the first scenario; knowledge-holders in the second) and has not an extensive focus on subject-matters, as opposed to anthropological scholars.

From the viewpoint of the research findings, in law, recognizing indigenous peoples as rights-holders has led to focus on the need to respect and promote ITK and benefits sharing, whereas ITK is informing ocean-centric approaches in ocean governance. The increasing influence of non-state actors in international (environmental) governance, initiated differentiated research on causes, context conditions, and consequences of this development in political science IR research. Albeit there are some more recent exceptions, Indigenous actors have thus far most often been studied as one example of non-state actor groups or subsumed under the category of NGOs.

The most important contributions of IR scholars for future interdisciplinary research on knowledge-integration may be reflections on the influence of the institutional design of international institutions on the scope and further impact of the inclusion of (indigenous) non-state actors and on the role of inherent power relations within the political process of the integration of different knowledge systems (primarily within Neo- and Decolonial Studies only). Moreover, IR research has provided new insights on the interplay of different types of political inclusion, especially the interaction of formal, informal, and mainly bottom-up modes and mechanisms of the inclusion of Indigenous/traditional knowledge holders. There is very little research in political science explicitly focusing on marine resource governance and ocean governance in general, however. So that the

\footnotetext{
${ }^{3}$ See for example: https://research.ncsu.edu/rdo/2020/08/the-differencebetween-multidisciplinary-interdisciplinary-and-convergence-research/. Accessed May 17, 2021.
}

validation of existing insights of IR research for the specific case of indigenous knowledge in marine resource governance is in large part still pending.

In anthropology and SES research, despite widespread interest in applying TEK and IK to fisheries and marine resource management, there are concerns about whose knowledge is privileged in the context of environmental governance. LEK is often seen as ancillary, secondary, subsidiary, qualitative, anecdotal, unreliable, messy, nostalgic, emotionally charged (Ames, 2001; Garcia-Quijano $\&$ Valdes-Pizzini, 2015). This is a problem because it overlooks an important dimension of "ecological thinking" that may be missed in scientific methods (Garcia-Quijano, 2015) as well as place-based, experiential knowledge that is often interwoven with complex systems of belief, practice, value, and power (Carothers et al., 2014).

From the viewpoint of the gaps, in law, an investigation is still missing on the possibilities of looking at the integration of knowledge in a multi-actor dimension; and the consequences of the dichotomy between ITK and science are not yet fully explored. The research gaps in political sciences are especially related to the marginalization of indigenous research. ${ }^{4}$ Moreover, the transferability of existing insights on non-state knowledge-holders in general to the specific topic of interest remains to be tested empirically. In anthropology, more attention should be given to the relationships of power that surround the production of knowledge that raise important epistemological questions of how knowledge is produced, whom it is produced for, why, whose knowledge is privileged over others, and how knowledge itself may be transformed or corrupted in the process of conducting research.

\section{Methodological Issues and Research Design}

Scholars from the three disciplines have used a broad range of quantitative and most notably qualitative methods of data collection and data analysis to study different aspects of indigenous and traditional knowledge integration. The most comprehensive methods, which increasingly also acknowledge that due to the inherent characteristics of indigenous

\footnotetext{
${ }^{4}$ For indigenous research we refer to the definition of Given (2008): "Indigenous research is systematic inquiry that engages Indigenous persons as investigators or partners to extend knowledge that is significant for Indigenous peoples and communities. Indigenous research is distinct from studies of Indigenous societies and issues that adopt a positivist position that behavior and meaning can be derived best from objective, value-neutral observation and data collection. The emergence of Indigenous research during the latter decades of the twentieth century was advanced by parallel developments in qualitative research methods, although divergence from certain conventions of academic practice continue to generate discussion and challenges.".
} 
knowledge systems, such as the dominantly oral tradition of knowledge transfer, the standard canon of methods of data gathering and analysis within "Western science" may produce inadequate insights, can certainly be found in anthropological research. As noted, anthropologists have used methods such as cultural models, ethnobiological interviews, or participatory mapping ("mental maps"), and grounded theory to better understand the application of indigenous knowledge, as well as its potential contribution to (marine) resource governance.

Political science IR research by tendency is much more dominated by analyses of governmental and organizational documents, but also includes interviews with (indigenous) knowledge holders, with a stronger focus on political representatives and fewer indigenous community members. A co-development of the overall research design and methodology together with indigenous representatives is still quite rare in political science IR research. Accordingly, indigenous methodologies rarely appear in IR research, mainly in decolonial studies.

Legal scholars mainly apply exploratory research, relying on secondary research to build a literature review. The secondary research combines a literature review on law and ocean governance relevant to the subject matter, and in sporadic cases includes discussions and empirical data collected during fieldwork, which is relevant in legal research on marine governance because it bridges academia and practice. Even though it is still adopted as exploratory and for small-scale case studies, it has the potential to inspire the design of future innovative methodological approaches, in the context of transdisciplinary research. In this regard it is necessary to explore ways of upscaling successful projects and making empiricism meaningful for legal analysis and policymaking. The format in which the research findings are reported is a critical literature review to establish an exploratory matrix of best practice examples and challenges relevant to the subject matter.

More recently, and in line with a growing demand for interdisciplinary research in marine and environmental sciences, new concepts such as the "co-production of knowledge" have gained some influence as guiding principles for researchers studying Indigenous Knowledge integration (see Tengö et al., 2014; Yumie Aoki Inoue, 2018). Co-production of knowledge can be defined as "is a mutual process of knowledge generation that engages actors at all stages, including validation" (Yumie Aoki Inoue, 2018: 31).

Concerning methodological questions, co-production of knowledge might inform reflections on the most effective ways to develop interdisciplinary research. Following insights of critical political science IR-research and in line with Chapman and Scott (2020), we argue that such reflections must take account of inherent power dynamics also determining the choice of research designs and methods.
In research practice, the implementation of such an approach of co-production of knowledge is still hindered by traditional (disciplinary) funding of research, which does not take into consideration resource constraints of indigenous community members, especially about the application phase of research, or simply excluding "non-scientific" actors from funding schemes. In general, established internal structures of research institutions (such as universities) impede a more comprehensive co-production of knowledge due to path dependencies of these institutions, which hamper more rapid adaption to changes in knowledge production (Krücken, 2003). Accordingly, crucial global expert organizations like the IPCC, playing a major role in informing and shaping climate (thus also natural resources) governance (Ford et al., 2016), still rarely include indigenous representatives, and IPCC reports are not co-authored by researchers of indigenous origin. This has consequences not only for the dominant definition and framing of indigenous knowledge within the IPCC (for details see above), but also for the limited spectrum of methodological approaches used and advocated. On the other hand, there are also emerging arguments for a paradigm shifts toward collaborative research and Indigenous methdologies in resource management, and especially in anthropology and archaeology (e/g., Atalay, 2019; Gordon, 2021; Turner, 2020).

\section{Conclusion: Towards a Common Understanding of Knowledge-Integration}

A growing number of scholars involved in interdisciplinary research on the marine environment acknowlege the value of ITK/TLK and advocate for its more comprehensive inclusion into research to extend the "collective knowledge base" (Christie, 2011; Fa et al., 2020: 82; Turner et al., 2017).

Building on such premise, we presented a three-disciplinary research overview about the theoretical and empirical insights, and identified further potential research gaps and blind spots concerning sustainable marine governance, and the integration of indigenous and traditional knowledge within the scientific disciplines of anthropology, law, and political science. In addition, we developed a critical synopsis of our research results in the three fields.

Our study reveals how research within the three disciplines offers foci, insights, and methodological approaches as promising starting points for future comprehensive multi-, inter-, and transdisciplinary research. However, we also argue that further research is needed on knowledge integration, and much further work is needed to achieve knowledge integration in marine governance research. A crucial first step towards the advancement of research consists in the development of an advanced conceptualization of the term "knowledge integration." We note that 
the three research fields have all recognized the need to develop a deeper understanding of knowledge integration (the common trait), but this is already hampered by the controversial and ambivalent definitions and interpretation of the term "integration" (Nadasdy, 2007; Wohling, 2009). Such contradictions are not exclusively a drawback, but also indicate where further collaborative research can provide productive new input.

Our analysis contributes to determining the crucial dimensions of knowledge integration as a basis for developing a conceptual framework. Insights from legal research illuminate how legal frameworks and their underlying conceptualization have excluded indigenous ontologies and legal orders in the systems of environmental and ocean governance. Political science IR research comparatively focuses on how institutional designs and relationships of power conditions in practice often exclude indigenous knowledge holders from institutional participation and political discourses. Anthropology and SES research has tackled the question of integration of scientific knowledge with indigenous knowledge, but in this process revealed biases in the research process and production of knowledge itself, evident in the fact that certain knowledge is privileged over others. Consequently, conflating important insights of the different research disciplines, a comprehensive conceptualization of indigenous and traditional knowledge integration should include the systematic assessment of the relationship between indigenous knowledge and knowledge-holders (actors) in the context of existing power relations within relevant institutions - including questions on political representation. Moreover, such conceptualization should be sensitive towards the influence of institutional designs of the specific political and/or legal process of knowledge integration. Institutional design choices such as internal decision-making rules of non-state actors (e.g., Indigenous Peoples) have also to be considered when determining knowledge integration. It is advisable to adopt an extensive interpretation also at a legislative level, one that highlights the need to integrate not only scientific knowledge in the fabric of public decisions (e.g., in environmental decision-making processes) but also traditional and indigenous knowledge systems. To ensure that knowledge systems work in harmony more effectively, anthropological and decolonial IR research offer crucial insights, looking critically into the semantic proximity of the term integration with experiences of forced assimilation from the perspective of various Indigenous scholars and political representatives (Lightfoot, 2016).

Critical reflections on epistemological (in-)compatibilities are finally highly relevant, as they have implications for the range of methods used within specific knowledge systems. Thus, the choice of research methods is an integral part of conceptualizing knowledge integration. To move forward, future research would have to address the highlighted limitations in each research field through collaborative approaches and connectivity across global and local scales.

Funding Open access funding provided by UiT The Arctic University of Norway (incl University Hospital of North Norway).

\section{Declarations}

Conflict of Interests All authors declare they have no conflict of interests related to the work submitted for publication.

Open Access This article is licensed under a Creative Commons Attribution 4.0 International License, which permits use, sharing, adaptation, distribution and reproduction in any medium or format, as long as you give appropriate credit to the original author(s) and the source, provide a link to the Creative Commons licence, and indicate if changes were made. The images or other third party material in this article are included in the article's Creative Commons licence, unless indicated otherwise in a credit line to the material. If material is not included in the article's Creative Commons licence and your intended use is not permitted by statutory regulation or exceeds the permitted use, you will need to obtain permission directly from the copyright holder. To view a copy of this licence, visit http://creativecommons.org/licenses/by/4.0/.

\section{References}

\section{Legislation and Reports}

AC. (1996). Arctic Council. Declaration on the Establishment of the Arctic Council, Ottawa, Canada, September 19, 1996.

CAFF. (2017-2019). Actions for Arctic Biodiversity: Progress Report 9. CBD. (1992). Convention on Biological Diversity.

FAO Report. (2009). http://www.fao.org/3/i0841e/i0841e00.pdf.

UNCLOS. (1982). United Nations Convention on the law of the sea.

UNDP. (2018). https://www.undp.org/content/undp/en/home/librarypage/ poverty-reduction/what-does-it-mean-to-leave-no-one-behind-.html. Visited 14.04.2021.

UNFCCC. (1992). United Nations Framework Convention on Climate Change: https://unfccc.int/files/essential_background/background_ publications_htmlpdf/application/pdf/conveng.pdf. Visited 14.04.2021.

\section{Scientific articles}

Agrawal, A. (1995). Dismantling the divide between indigenous and scientific knowledge. Development and Change, 26(3), 413-439.

Albin, C. (1999). Can NGOs enhance the effectiveness of international negotiation? International Negotiation, 4(3), 371-387.

Am, H. M. (2019). Emerging trends in the generation, transmission and protection of Traditional Knowledge, 2019, Indigenous Policy Journal, vol. 30 (1) Republished from the United Nations Permanent Forum on Indigenous Issue, 18th Session, 2019.

Ames, E. P. (2001). Putting Fishermen's Knowledge to Work. Conference Proceedings: 27-30 August 2001; Vancouver. Edited by Haggan N, Brignall C, Wood L. Vancouver: FCRR; 2003:228-204.

Amiott, J. (2003). Investigating the Convention on Biological Diversity's Protections for Traditional Knowledge. Missouri Environmental Law and Policy Review - Journal of Environmental and Sustainability Law, 11(1), 2-37. 
Andersen S., Gulbrandsen L.H. (2003). The role of green NGOs in promoting climate compliance. Fridtjof Nansen Institute Report No.4.

Andresen, S., Skodvin, T., Underdal, A., \& Wettestad, J. (2000). Science and Politics in International Environmental Regimes. Between Integrity and Involvement. Manchester University Press.

Aswani, S. (2011). Socioecological approaches for combining ecosystem-based and customary management in Oceania. Journal of Marine Biology. Article ID 845385. https://doi.org/10.1155/ 2011/845385.

Aswani, S., \& Hamilton, R. J. (2004). Integrating Indigenous Ecological Knowledge and Customary Sea Tenure with Marine and Social Science for Conservation of Bumphead Parrotfish (Bolbometopon muricatum) in the Roviana Lagoon. Solomon Islands. Environmental Conservation, 31(1), 69-83.

Aswani, S., \& Lauer, M. (2006). Incorporating Fishermen's Local Knowledge and Behavior into Geographical Information Systems (GIS) for Designing Marine Protected Areas in Oceania. Human Organization, 65(1), 81-102.

Aswani, S., Lemahieu, A., \& Sauer, W. H. H. (2018). Global trends of local ecological knowledge and future implications. PLoS One, 13(4), e0195440. https://doi.org/10.1371/journal.pone.0195440

Atalay, S. (2019). Can Archaeology Help Decolonize the Way Institutions Think? How Community-Based Research is Transforming the Archaeology Training Toolbox and Helping to Transform Institutions. Archaeologies, 15, 514-535.

Atran, S. (1993). Whither "ethnoscience"? In P. Boyer (Ed.), Cognitive aspects of religious symbolism (pp. 48-70). Cambridge University Press.

Atran, S., Medin, D., Ross, N., Lynch, E., Coley, J., Ek, E. U., \& Vapnarsky, V. (1999). Folkecology and Commons Management in the Maya Lowlands. PNAS, 96(13), 7598-7603. https://doi.org/10.1073/pnas. 96.13.7598

Beitl, C. M., Chávez Páez, W., Vanegas Redondo, W. F., Carvajal Cañarte, E. L., Zambrano Mohauad, G. A., Alfonso Ramírez, K. R., and Gortaire Díaz, D. E. (2020). Cambios Socio-ambientales, Alimentación y Sustento en una Comunidad Rural del Manglar. INVESTIGATIO(13), 89-102. https://doi.org/10.31095/investigatio.2020.13.9.

Bélisle, A. C., Asselin, H., LeBlanc, P., \& Gauthier, S. (2018). Local knowledge in ecological modeling. Ecology and Society, 23(2).

Bender, M. G., Floeter, S. R., \& Hanazaki, N. (2013). Do traditional fishers recognise reef fish species declines? Shifting environmental baselines in Eastern Brazil. Fisheries Management and Ecology, 20, 58-67.

Bennett, M. M. (2020). Scale-jumping in the Arctic Council: Indigenous permanent participants and Asian observer states. In C. Y. Woon \& K. Dodds (Eds.), 'trObserving' the Arctic: Asia in the Arctic Council and beyond. Edward Elgar Publishing Limited, 54-81.

Berlin, B., Breedlove, D., \& Raven, P. H. (1973). General principles of classification and nomenclature in folk biology. American Anthropologist, 75(1), 214-242.

Bernauer, T., \& Gampfer, R. (2013). Effects of Civil Society Involvement on Popular Legitimacy of Global Environmental Governance. Global Environmental Change 23/2: 439-449., Available at SSRN: https://ssrn.com/abstract $=3080292$.

Betsill, M. M., \& Corell, E. (2001). NGO Influence in International Environmental Negotiations: A Framework for Analysis. Global Environmental Politics, MIT Press, 1(4), 65-85.

Biermann, F., \& Gupta, A. (2011). Accountability and legitimacy in earth system governance: A research framework. Ecological Economics, 70, 1856-1864.

Birnie P., Boyle, A., \& Redgwell C. (2009). International Law and the Environment, Oxford.

Blaney, D. L., \& Tickner, A. B. (2017). Worlding, ontological politics and the possibility of a decolonial IR. Millennium, 45(3), 293-311.
Boyes, S. J., Michael Elliott, M. (2014). Marine legislation - The ultimate 'horrendogram': International law, European directives \& national implementation. Marine Pollution Bulletin, 86, (1-2), 39-47, ISSN 0025-326X, https://doi.org/10.1016/j.marpolbul. 2014.06.055.

Brhlíková, L. (2017). Traditional and Local Knowledge in the Arctic. Aalborg University, Copenhagen, Denmark.

Brown Weiss, E. (2011). The Evolution of International Environmental Law, 54 Japanese Y.B. Intl. L.

Buck, M., Hamilton, C. (2011). The Nagoya Protocol on Access to Genetic Resources and the Fair and Equitable Sharing of Benefits Arising from their Utilization to the Convention on Biological Diversity, Review of European Community and International Environmental Law, 2011, Vol. 20 (1), 47-61.

Bulmer, R. (1967). Why is the cassowary not a bird? A problem of zoological taxonomy among the Karam of the New Guinea Highlands. Man, 2, 2-25.

Bäckstrand, K. (2003). Civic Science for Sustainability: Reframing the Role of Experts, Policy-Makers and Citizens in Environmental Governance. Global Environmental Politics, MIT Press, 3(4), $24-41$.

Carothers, C., Brown, C., Moerlein, K. J., López, J. A., Andersen, D. B., \& Retherford, B. (2014). Measuring perceptions of climate change in northern Alaska: pairing ethnography with cultural consensus analysis. Ecology and Society, 19(4).

Casagrande, D. G. (2004). Conceptions of Primary Forest in a Tzeltal Maya Community: Implications for Conservation. Human Organization, 63(2), 189-202. https://doi.org/10.17730/humo. 63.2.tjtaa6vwkcja1jh7

Casimirri, G. (2003). Problems with Integrating Traditional Ecological Knowledge into Contemporary ResourceManagement (XII World Forestry Congress, Quebec, 21-28 September 2003) http://www. fao.org/3/XII/0887-A3.htm\#P24_2299.

Chapman, J., Schott, S. (2020). Knowledge coevolution: generating new understanding through bridging and strengthening distinct knowledge systems and empowering local knowledge holders. Sustainability Science, 1-13.

Christie, P. (2011). Creating space for interdisciplinary marine and coastal research: Five dilemmas and suggested resolutions. Environmental Conservation, 38(2), 172-186.

Cicin-Sain, B. (1993). Integrated Coastal Management Sustainable development and integrated coastal management. Ocean \& Coastal Management, 21, 11-43.

Coote, L. M. (2016). Environmental Decision-Making in the Arctic Council: What s the Role of Indigenous Peoples? 2016 Arctic Yearbook. https://www.arcticyearbook.com. Visited in April 14, 2021.

De Freitas, D. M., \& Tagliani, P. R. A. (2009). The use of GIS for the integration of traditional and scientific knowledge in supporting artisanal fisheries management in southern Brazil. Journal of Environmental Management, 90(6), 2071-2080. https://doi.org/ 10.1016/j.jenvman.2007.08.026

Diver, S. (2017). Negotiating Indigenous Knowledge at the Sciencepolicy Interface: Insights from the Xáxli’p Community Forest. Environmental Science \& Policy, 73, 1-11. https://doi.org/10. 1016/j.envsci.2017.03.001

Dunn, D.C., Crespo, G.O., Vierros, M., Freestone, D., Rosenthal, E., Roady, S., Alberini, A., Harrison, A.-L., Cisneros, A., Moore, J. W., Sloat, M.R., Ota, Y., Caddell, R., and Halpin, P.N. (2017). Adjacency: How legal precedent, ecological connectivity, and Traditional Knowledge inform our understanding of proximity [POLICY BRIEF - UN PrepCom 3].

Early-Capistrán, M.-M., Solana-Arellano, E., Abreu-Grobois, F. A., Narchi, N. E., Garibay-Melo, G., Seminoff, J. A., \& SaenzArroyo, A. (2020). Quantifying local ecological knowledge to 
model historical abundance of long-lived, heavily-exploited fauna. PeerJ, 8, e9494. https://doi.org/10.7717/peerj.9494

Esguerra, A., van der Hel S. (2021). Participatory Design and Epistemic Authority in Knowledge Platforms for Sustainability. Global Environmental Politics, forthcoming.

Fa, J. E., Watson, J. E., Leiper, I., Potapov, P., Evans, T. D., Burgess, N. D., \& Garnett, S. T. (2020). Importance of Indigenous Peoples' lands for the conservation of Intact Forest Landscapes. Frontiers in Ecology and the Environment, 18(3), 135-140.

Fabbi, N. C. (2015). Inuit Nunaat as an emerging region in area studies: Building an Arctic studies program south of the tree line. University of British Columbia Library. https://doi.org/10. $14288 / 1.0135711$

Fan, R. C. (2014). Governing Indigenous Knowledge? A Study of International Law, Policy, and Human Rights. A thesis submitted for the degree of Doctor of Philosophy (Ph.D.) Department of Sociology, University of Essex, December 2014, available at: http://repository.essex.ac.uk/16538/1/RCFan\%20PhD_final.pdf.

Farr, E. R., Stoll, J. S., \& Beitl, C. M. (2018). Effects of fisheries management on local ecological knowledge. Ecology and Society, 23(3), 15. https://doi.org/10.5751/ES-10344-230315

Feurt, C. (2006). Cultural Models - a Tool for Enhancing Communication and Collaboration in Coastal Resources Management: A Primer for Coastal Training Program Coordinators. In National Estuarine Research Reserves. Paper 17, http://dune.une.edu/env facpubs/17?utm_source=dune.une.edu $\% 2$ Fenv_facpubs $\% 2$ F $17 \&$ utm_medium $=$ PDF\&utm_campaign $=$ PDFCoverPages.

Flores Alonso, M. (2008). Can We Protect Indigenous Knowledge? In Boaventura de Sousa Santos (Ed.): Another knowledge is possible. Beyond northern epistemologies. London: Verso. 249. - 271.

Ford, J. D., Cameron, L., Rubis, J., Maillet, M., Nakashima, D., Willox, A. C., \& Pearce, T. (2016). Including indigenous knowledge and experience in IPCC assessment reports. Nature Climate Change, 6(4), 349-353.

Forsyth, M. (2013). How Can the Theory of Legal Pluralism Assist the Traditional Knowledge Debate?, Intersections: Gender and Sexuality in Asia and the Pacific, 33.

Fowler, C. (1977). Ethnoecology. In D. L. Hardesty (Ed.), Ecological Anthropology. New York: Wiley.

Foyer, J., Kervran, D. D. (2017). Objectifying traditional knowledge, re-enchanting the struggle against climate change. Aykut Stefan; Foyer Jean; Morena Edouard. Globalising the Climate. COP21 and the climatisation of global debates, Routledge, 9781138675599.

García G., \& Suyai, M. (2016). Mujeres Mapuce, Extractivismo y Kvme Felen (Buen Vivir): La lucha por los bienes comunes en Neuquén. In MILLCAYAC - Revista digital de Ciencas Sociales 3 (4), pp. 15-39. ISSN:2362-616x

García-Quijano, C. G., Poggie, J. J., Pitchon, A., \& Del Pozo, M. H. (2015). Coastal resource foraging, life satisfaction, and wellbeing in southeastern Puerto Rico. Journal of Anthropological Research, 71(2), 145-167.

García-Quijano, C. G. (2007). Fishers' Knowledge of Marine Species Assemblages: Bridging between Scientific and Local Ecological Knowledge in Southeastern Puerto Rico. American Anthropologist, 109(3), 529-536. https://doi.org/10.1525/aa.2007.109.3.529

García -Quijano, C. G., \& Valdes-Pizzini, M. (2015). Ecosystem-based knowledge and reasoning in tropical, multi-species, small-scale fishers' LEK: What can fishers' LEK contribute to coastal ecological science and management? In J. Fischer, J. Jorgensen, H. Josupeit, \& D. Kaliksoski (Eds.), Fishers' Knowledge and the Ecosystem Approach to Fisheries.

Gereke, M., \& Brühl, T. (2019). Unpacking the unequal representation of Northern and Southern NGOs in international climate change politics. Third World Quarterly, 40(5), 870-889. https://doi.org/ 10.1080/01436597.2019.1596023
Gissi, N., Ibacache, D., Padro, B., \& Ñancucheo, M. C. (2017). El Estado chileno, los lafkenche y la Ley 20.249. ¿Indigenismo o política del reconocimiento? In Revista Austral De Ciencias Sociales, 32, 5-21.

Given, L. M. (2008). The SAGE encyclopedia of qualitative research methods (Vols. 1-0). Thousand Oaks, CA: SAGE Publications, Inc. doi: https://doi.org/10.4135/9781412963909.

Goodenough, W. H. (1957). Cultural Anthropology and Linguistics. Georgetown University Monograph Series on Language and Linguistics, 9, 167-173.

Gordon HSJ. (2021). Ethnographic futures research as a method for working with Indigenous communities to develop sustainability indicators. Polar Geography: 1-22

Green, L. (2013). Contested ecologies: dialogues in the South on nature and knowledge. HSRC Press.

Grip, K. (2017). International marine environmental governance: A review. Ambio, 46, 413-427. https://doi.org/10.1007/ s13280-016-0847-9

Haas, P. (1992). Introduction: Epistemic Communities and International Policy Coordination. International Organization 46: 1, Knowledge, Power and International Policy Coordination (Winter), 1-35.

Harrison, J. (2015). The Law of the Sea Convention Institutions, in Rothwell D. R., Oude Elferink, A., Scott, K., and Stephens, T. (eds.). The Oxford Handbook of the Law of the Sea.

Hasenclever, A., \& Narr, H. (2019). The dark side of the affectednessparadigm: lessons from the Indigenous peoples' movement at the United Nations, Third world thematics - London : Taylor \& Francis Group, Bd. 3, H. 5-6, 684-702.

Hind, E. (2014). Climate change and adaptation strategies in the Turks and Caicos islands: using qualitative citizen science to discover experiential knowledge. SAGE Publications, Ltd.

Hunn, E. (1982). The utilitarian factor in folk biological classification. American Anthropologist, 84(4), 830-847.

Inuit Circumplar Circle (2011). The Sea Ice Never Stops: Circumpolar Inuit Reflections on Sea Ice Use and Shipping in Inuit Nunaat.

Jakobsen, I. U., \& Poto, M.P.P. (2016). Biodiversity conservation in the Arctic: the Norwegian perspective, in Environmental Liability: Law, Policy and Practice: 165-174.

Johannes, R. E. (1978). Traditional Marine Conservation Methods in Oceania and their Demise. Annual Review of Ecology and Systematics, 9, 349-364.

Johannes, R.E. (1981). Words of the Lagoon - fishing and marine lore in the Palu District of Micronesia. University of California Press, 245p.

Johannes, R. E., Freeman, M. M. R., \& Hamilton, R. J. (2000). Ignore fishers' knowledge and miss the boat. Fish and Fisheries, 1(3), 257-271. https://doi.org/10.1111/j.1467-2979.2000.00019

Koskenniemi, M. (2006). Fragmentation of International Law: Difficulties Arising from the Diversification and Expansion of International Law. Report, UN General Assembly.

Krücken, G. (2003). Learning the „New, New Thing“. On the Role of Path Dependency in University Structures. Higher Education 46 (3), 315-339

Kuhnlein, H. V. (2014). How Ethnobiology Can Contribute to Food Security. Journal of Ethnobiology, 34(1), 12-27, 16.

Kutty, P.V.V.G. (2002). National Experiences with the Protection of Traditional Cultural Expressions/Expressions of Folklore (WIPO).

Latulippe, N., \& Klenk, N. (2020). Making room and moving over. Knowledge co-production, Indigenous knowledge sovereignty and the politics of global environmental change decision-making. In Current Opinion in Environmental Sustainability, 42, 7-14. https://doi.org/10.1016/j.cosust.2019.10.010

Levine, A. S., \& Feinholz, C. L. (2015). Participatory GIS to inform coral reef ecosystem management: Mapping human coastal and 
ocean uses in Hawaii. Applied Geography, 59, 60-69. https://doi. org/10.1016/j.apgeog.2014.12.004

Lightfoot, S. R., MacDonald, D. (2017). Treaty Relations between Indigenous Peoples. Advancing Global Understandings of SelfDetermination. In New Diversities 19 (2). 25-39.

Lightfoot, S. R. (2016). Global indigenous politics. A subtle revolution. Routledge.

Lloret, J., Sabatés, A., Muñoz, M., Demestre, M., Solé, I., Font, T., \& Gómez, S. (2015). How a multidisciplinary approach involving ethnoecology, biology and fisheries can help explain the spatio-temporal changes in marine fish abundance resulting from climate change. Global Ecology and Biogeography, 24(4), 448-461.

Maaka, R., \& Fleras, A. (2009). Mainstreaming Indigeneity by Indigenizing Policymaking. Towards an Indigenous grounded analysis framework as policy paradigm. In Indigenous Policy Journal 20 (3), 1-22.

Macdonald, David B. (2013). Reconciliation after Genocide in Canada. Towards a syncretic model of democracy. In AlterNative: An International Journal of Indigenous Peoples 9 (1), 60-73. https:// doi.org/10.1177/117718011300900105.

Marimán, J., Aylwin, P. (2008). Las identidades territoriales mapuche y el Estado chileno: conflicto interétnico en un contexto de globalización. In Xochitl Leyva Solano, Aracely Burguete Cal y Mayor, Shannon Speed (Eds.): Gobernar (en) la diversidad. Experiencias indígenas desde América Latina: hacia la investigación de colabor. 1. ed.

Markkula, I., Turunen, M. T., \& Kantola, S. (2019). Traditional and local knowledge in land use planning: Insights into the use of the Akwé: Kon Guidelines in Eanodat. Finnish Sápmi. Ecology and Society, 24(1), 20. https://doi.org/10.5751/ES-10735-240120

Mauro, F., \& Hardison, P. (2000). Traditional knowledge of indigenous and local communities: International debate and policy initiatives. Ecological Applications, 10(5), 1263-1269.

Mazzocchi, F. (2006). Western science and traditional Knowledge, 7(5) in EMBO reports, vol. 7(5), 464.

McLain, R., Poe, M., Biedenweg, K., Cerveny, L., Besser, D., \& Blahna, D. (2013). Making Sense of Human Ecology Mapping: An Overview of Approaches to Integrating Socio-Spatial Data into Environmental Planning. Human Ecology, 1-15. https://doi. org/10.1007/s10745-013-9573-0.

Morrill, W. T. (1967). Ethnoicthyology of the Cha-Cha. Ethnology, 6(4), 405-416.

Nadasdy, P. (2007). The gift in the animal: The ontology of hunting and human-animal sociality. American Ethnologist, 34(1), 25-43. https://doi.org/10.1525/ae.2007.34.1.25

Narchi, N. E., Cornier, S., Canu, D. M., Aguilar-Rosas, L. E., Bender, M. G., Jacquelin, C., \& de Wit, R. (2013). Marine ethnobiology a rather neglected area, which can provide an important contribution to ocean and coastal management. Ocean \& Coastal Management. https://doi.org/10.1016/j.ocecoaman.2013.09.014

Nasiritousi, N. (2019). NGOs and the Environment. In T. Davies (Ed.), Routledge Handbook of NGOs and International Relations (pp. 329-342). Routledge.

Nelson, M., \& Shilling, D. (Eds.). (2018). Traditional Ecological Knowledge: Learning from Indigenous Practices for Environmental Sustainability (New Directions in Sustainability and Society). Cambridge: Cambridge University Press. https://doi. org/10.1017/9781108552998.

Nijar, G. S. (2013). Traditional Knowledge Systems, International Law and National Challenges: Marginalization or Emancipation?, The European Journal of International Law, 24(4).

Olsen, S. B., Tobey, J., \& Hale, L. Z. (1998). A Learning-Based Approach to Coastal Management. Ambio, 27, 611-619.
Paolisso, M. (2002) Blue Crabs and Controversy on the Chesapeake Bay: A Cultural Model for Understanding Watermen's Reasoning about Blue Crab Management. Human Organization, 61.

Paolisso, M. (2007). Cultural models and cultural consensus of Chesapeake Bay blue crab and oyster fisheries. Napa Bulletin, 28(1), 123-135.

Paolisso, M., \& Dery, N. (2010). A Cultural Model Assessment of Oyster Restoration Alternatives for the Chesapeake Bay. Human Organization, 69, 169-179.

Petersson, M. T., Dellmuth, L. M., Merrie, A., \& Österblom, H. (2019). Patterns and trends in non-state actor participation in regional fisheries management organizations, Marine Policy, Volume 104. ISSN, 146-156, 0308-597X. https://doi.org/10.1016/j.marpol. 2019.02 .025

Poto, M. P. (2021). Thinking of Ocean Governance: By Whom, For Whom?, in V. De Lucia, A. Oude Elferink, L. Nguyen (eds.), The Areas Beyond National Jurisdiction, forthcoming, Brill.

Prakash, A., \& Gugerty, M. K. (2010). Advocacy organizations and collective action: An introduction. Advocacy Organizations and Collective Action, 1-28.

Reiter, B. (2017) Theory and Methodology of Exploratory Social Science Research. Government and International Affairs Faculty Publications. 132. http://scholarcommons.usf.edu/gia_facpub/132.

Rhoades, R. E., \& Booth, R. H. (1982). Farmer-back-to-farmer: A model for generating acceptable agricultural technology. Agricultural Administration, 11(2), 127-137. https://doi.org/10.1016/ 0309-586X(82)90056-5

Rickenbach, O., Reyes-García, V., Moser, G., \& García, C. (2017). What Explains Wildlife Value Orientations? A Study among Central African Forest Dwellers. Human Ecology, 45(3), 293 306. https://doi.org/10.1007/s10745-016-9860-7

Ruddle, K. (1994). Local Knowledge in the Folk Management of Fisheries and Coastal Marine Environments. In C. L. Dyer \& J. R. McGoodwin (Eds.), Folk Management in the World's Fisheries: Lessons for Modern Fisheries Management (pp. 161-206). University Press ofo Colorado.

Ruddle, K. (1995). The Role of Validated Local Knowledge in the Restoration of Fisheries Property Rights: The Example of the New Zealand Maori. In S. Hanna \& M. Munasinghe (eds.), Property Rights in a Social and Ecological Context: Case Studies and Design Applications, Washington, D.C., U.S.A.: Beijer International Institute of Ecological Economics and the World Bank, 112-120.

Ruddle, K., \& Akimichi, T. (1984). Maritime institutions in the Western Pacific. Osaka: National Museum of Ethnology.

Ruggie, J. (1975). International responses to technology: Concepts and trends. International Organization, 29(3), 557-583. https://doi. org/10.1017/S0020818300031696

Sáenz-Arroyo, A., Roberts, C. M., Torre, J., Cariño-Olvera, M., \& Enríquez-Andrade, R. R. (2005). Rapidly shifting environmental baselines among fishers of the Gulf of California. Proceedings of the Biological Sciences, 272, 1957-1962.

Santos, B. D. S. (2016). Epistemologies of the South and the future. From the European South: a transdisciplinary. Journal of Postcolonial Humanities, (1), 17-29.

Schatz, V. (2019). The Incorporation of Indigenous and Local Knowledge into Central Arctic Ocean Fisheries Management, Arctic Review on Law and Politics. 10, 130-134.

Scholte, J. A. (2011). Towards greater legitimacy in global governance. Review of International Political Economy, 18(1), 110-120. https://doi.org/10.1080/09692290.2011.545215

Schroeder, H., \& Lovell, H. (2012). The role of non-nation-state actorsand side events in the international climate negotiations. Climate Policy, 12(1), 23-37. https://doi.org/10.1080/14693062. 2011.579328

Shadian, J. M. (2017). Reimagining political space: The limits of Arctic indigenous self-determination in international governance? In 
K. Keil \& S. Knecht (Eds.), Governing Arctic change: Global perspectives (pp. 43-57). Palgrave MacMillan.

Sillitoe, P. (1998). The Development of Indigenous Knowledge: A New Applied Anthropology. Current Anthropology, 39(2), 223-252Berkes, F. (2015). Coasts for People. Interdisciplinary Approaches to Coastal and Marine Resource Management, Routledge.

Simpson, L. R. (2004). Anticolonial Strategies for the Recovery and Maintenance of Indigenous Knowledge. In the American Indian Quarterly, 28(3), 373-384. https://doi.org/10.1353/aiq.2004. 0107

Skodvin, T., \& Andresen, S. (2003). Nonstate Influence in the International Whaling Commission, 1970-1990 November 2003. Global Environmental Politics, 3(4), 61-86. https://doi.org/10. 1162/152638003322757934

Smith, L. T. (2012). Decolonizing methodologies. Research and indigenous peoples /Linda Tuhiwai Smith (2nd ed.). Zed Books.

Sturtevant, W. C. (1964). Studies in Ethnoscience 1. American Anthropologist, 66(3), 99-131.

Tallberg, J., Sommerer, T., Theresa Squatrito, T., Christer Jönsson, C. (2013). The Opening Up of International Organizations: Transnational Access in Global Governance (New York, NY: Cambridge University Press).

Tengö, M., Brondizio, E. S., Elmqvist, T., Malmer, P., \& Spierenburg, M. (2014). Connecting diverse knowledge systems for enhanced ecosystem governance: the multiple evidence base approach. Ambio, 43(5), 579-591.

Todd, Z. (2016). An Indigenous Feminist's Take On The Ontological Turn. ‘Ontology' Is Just Another Word For Colonialism: An Indigenous Feminist's Take on the Ontological Turn. In Journal of Historical Sociology 29 (1), 4-22. https://doi.org/10.1111/ johs.12124.

Trippett, F. (2000). Towards a Broad-Based Precautionary Principle in Law and Policy: A Functional Role for Indigenous Knowledge Systems (TEK) Within Decision-Making Structures (Dalhousie University), 4.

Tsiouvalas, A. (2020). Don’t Wake the Rávga of Repparfjord" Sámi Storytelling to Discuss Nussir ASA's Mining Waste Disposal, Master's Thesis, Faculty of Social Sciences, Humanities and Education, University of Troms $\varnothing, 66-75$.

Turner, N. J. (2020). From "taking" to "tending": learning about Indigenous land and resource management on the Pacific Northwest Coast of North America. ICES Journal of Marine Science

Turner, D. (2006). This is not a peace pipe. Towards critical indigenous philosophy/Dale Turner. University of Toronto Press.
Turner, L. M., Bhatta, R., Eriander, L., Gipperth, L., Johannesson, K., Kadfak, A., Karunasagar, I., Karunasagar, I., Knutsson, P., Laas, K., Moksnes, P.-O., \& Godhe, A. (2017). Transporting ideas between marine and social sciences: Experiences from interdisciplinary research programs. Elem Sci Anth, 5, 14.

Van Tatenhove, J.P.M. (2011). Integrated marine governance: Questions of Legitimacy. MAST 2011, 10 (1): 87-113.

Velasquez Runk, J. (2014). Enriching indigenous knowledge scholarship via collaborative methodologies: beyond the high tide's few hours. Ecology and Society 19

Viaña-Uzieda, J. (2009). La interculturalidad como herramienta de emancipación. Hacia una redefinición de la interculturalidad y de sus usos estatales (1st ed.). Instituto Internacional de Integración.

Weller, S. C. (2007). Cultural Consensus Theory: Applications and Frequently Asked Questions. Field Methods, 19(4), 339-368. https://doi.org/10.1177/1525822X07303502

Whitt, L. (2009). Science, Colonialism, and Indigenous Peoples. Cambridge University Press.

Wohling, M. (2009). The problem of scale in indigenous knowledge: a perspective from northern Australia. Ecology and Society, 14 (1).

Young, O. (1999). The Effectiveness of International Environmental Regimes. Causal Connections and Behavioral Mechanisms. MIT Press.

Young, O. (2004). The consequences of international regimes. In Regime Consequences (pp. 3-23). Springer, Dordrecht.

Yumie Aoki Inoue, C. (2018). Worlding the Study of Global Environmental Politics in the Anthropocene: Indigenous Voices from the Amazon, Global Environmental Politics, MIT Press: 18(4).

Zapelini, C., Bender, M. G., Giglio, V. J., \& Schiavetti, A. (2019). Tracking interactions: Shifting baseline and fisheries networks in the largest Southwestern Atlantic reef system. Aquatic Conservation: Marine and Freshwater Ecosystems, 29, 2092-2106.

Zapelini, C., Giglio, V. J., Carvalho, R. C., Bender, M. G., \& Gerhardinger, L. C. (2017). Assessing fishing experts' knowledge to improve conservation strategies for an endangered grouper in the Southwestern Atlantic. Journal of Ethnobiology, 37(3), 478-493. https://doi.org/10.2993/0278-0771-37.3.478

Publisher's Note Springer Nature remains neutral with regard to jurisdictional claims in published maps and institutional affiliations. 